Staging data: Theatre as a tool for analysis and knowledge transfer in health research

$$
\begin{aligned}
& \text { Kate Rossiter }^{1} \text {, Pia Kontos }{ }^{1,2} \text {, Angela Colantonio }{ }^{2,4} \text {, Julie Gilbert }{ }^{5,6} \text {, } \\
& \text { Julia Gray }^{7} \text {, Michelle Keightley }{ }^{4}
\end{aligned}
$$

${ }^{1}$ Department of Public Health Sciences, University of Toronto, 155 College Street, Toronto, Ontario, Canada.

${ }^{2}$ Toronto Rehabilitation Institute, Toronto, Ontario, Canada.

${ }^{4}$ Department of Occupational Science and Occupational Therapy, University of Toronto, Toronto, Ontario, Canada.

${ }^{5}$ Department of Health Policy Management and Evaluation, University of Toronto, Toronto, Ontario, Canada.

${ }^{6}$ The Change Foundation, Toronto, Ontario, Canada.

${ }^{7}$ Department of Theatre, York University, Toronto, Ontario, Canada. 


\title{
Staging data: Theatre as a tool for analysis and knowledge transfer in health research
}

\begin{abstract}
Over the past several decades, researchers have taken an interest in theatre as a unique method of analyzing data and translating findings. Because of its ability to communicate research findings in an emotive and embodied manner, theatre holds particular potential for health research, which often engages complex questions of the human condition. In order to evaluate the research potential of theatre, this article critically examines examples of evaluated health research studies that have used theatre for the purposes of data analysis or translation. We examine these studies from two perspectives. First, the literature is divided and categorized into four theatre genres: 1) non-theatrical performances; 2) ethnodramas, which can be interactive or non-interactive; 3) theatrical research-based performances; and 4) fictional theatrical performances. This categorization highlights the importance of these genres of theatre and provides an analysis of the benefits and disadvantages of each, thus providing insight into how theatre may be most effectively utilized in health research. Second, we explore the efficacy of using theatre for the purposes of data analysis and knowledge transfer, and critically examine potential approaches to the evaluation of such endeavours.
\end{abstract}




\section{Introduction}

Since its inception as an art form, theatre, or dramatic representation, has been used not only for the purposes of entertainment, but also as a means to inspire thought, critical reflection, emotional engagement and personal transformation. While theatre has a rich history of imparting information and encouraging thought, reflection and insight, formal ties between theatre and research, particularly in terms of the analysis and translation of research results, have developed only relatively recently, over the past three decades (Gray \& Sinding, 2002). Despite theatre's demonstrated abilities to engage, entertain and communicate complex information in a nuanced manner that transcends the limitations of text (Paget, 1993), researchers (and dramatists) have been slow to bridge this disciplinary chasm. Theatre has a unique potential to interpret, translate and disseminate research findings. This is especially true for medical and health-related knowledge, which often revolves around complex questions of the embodied human condition, and which is frequently confined to academic manuscripts and often fails to inform those outside academic settings (Gray, Sinding, Ivonoffski, Fitch, Hampson, \& Greenberg, 2000;

Mienczakowski, Smith \& Morgan, 2002).

Given the promise of theatre to provide new opportunities for the analysis, representation and transfer of data, health researchers have begun to show an interest in performance as a means of interpreting, enlivening and enriching their findings. In this literature review we examine examples of research-based theatrical productions in the field of health. The aim of this review is to compile, categorize and critically examine work in this area that has been done to date. Through this review we offer an analysis of theatre's potential as a medium for the interpretation and transfer of health-based research. This review will unfold in two parts. First, we categorize the gathered examples of theatre-based health research into four theatrical genres. The goal of 
this categorization is to explore a variety of theatrical approaches used in theatre-based research, and to examine the benefits and drawbacks of each approach. Second, in order to better understand the impact and efficacy of theatre-based health research, we discuss the evaluations of the projects under examination. Here, we explore two aspects of the evaluative process: 1) the results that these evaluations have generated, and 2) an overall analysis regarding the difficulties that arise when evaluating theatre-based health research projects. Given that theatre is a new phenomenon in research, its efficacy is still largely unknown. Thus, a careful examination of the evaluation of research-based theatre projects is warranted.

\section{Methodology}

Because theatre-based health research necessarily spans across many fields, including psychology, biomedical research, performance studies and literature studies, we were unable to conduct a conventional systematic search of the literature by discipline. For this review we have chosen to focus on health-related theatre projects wherein the projects themselves have been empirically evaluated in some way. Our search spanned many disparate databases, including several variants of Medline, and all of the relevant art/humanities and social science databases in Scholar's Portal. Further, these searches required the use of multiple keywords and keyword combinations, each leading to only partial areas of the relevant, available literature. In particular, background and theoretical articles informing the use of drama for health-related research and education were notably absent from the found literature. Further, the multiple applications of the chosen search terms, chiefly “theatre,” “performance,” and “drama,” complicated the search. Medical database searches, for example, included many articles discussing research regarding operating theatres - a use of the term clearly not relevant to our review. Given these challenges, a second approach to searching the literature was implemented. Working from the 
bibliographies and citations of found literature, a "snowball” sampling technique (Babbie \& Benaquisto, 2002, p. 166) was utilized to locate additional studies, and to provide a fuller account of the state of current research in this area.

Once collected, the literature was organized in a coherent, systematic manner. For the purposes of this article, we have divided this literature into four performance genres: 1) nontheatrical performances; 2) ethnodramas, which can be interactive or non-interactive; 3) theatrical research-based performances; and 4) fictional theatrical performances. This classification places theatrical style (as opposed to research method, for example) at the forefront of analysis, and represents a continuum, moving from a very close alignment with data to purely fictional accounts of health-related topics. It is important to note here that we developed and imposed these categories upon the literature for the purposes of this article; these genres did not exist previously, and were created as an analytic tool to understand the ways in which theatre has been used in health research. We further divided the literature by the method of evaluation used to assess the effectiveness of the performance. This division moves from projects that were evaluated in an informal manner, to projects that were subjected to a rigorous, formal evaluative process.

\section{Four Genres of Performance: Description and Analysis}

In our exploration of the four genres of theatre-based health research we identify some of the benefits that theatre may hold in relation to more traditional research methods. By using theatre, or theatrical techniques, health care providers may better understand, and therefore cope with, issues in practice that are complex, interpersonal, emotional, and embodied. Our exploration of the ways that theatre has been used to address these issues includes a range of theatricality: The literal dramatization, or staging of data; the creation of interactive theatre 
pieces based on research; research-based plays that theatricalize or fictionalize the data; and performances that do not rely at all on primary data, but nonetheless have been used and evaluated for their efficacy as tools for imparting health-related information. We have included the origins of each particular use of theatre as well as an analysis regarding the strengths and limitations of each theatrical approach. It is important to recognize that some of these uses of theatre can fit into multiple genres. However, given our objective to provide a clear presentation of when and how theatre has been used in the analysis and transfer of health research, it is our contention that dividing the literature along the lines of theatrical genre is the most informative, and potentially an instructive means to allow others to decide how (or how not) to stage and dramatize their own research. If theatre is to be used as an effective tool for health research, we feel it is imperative to understand theatre-based health research projects in theatrical, as opposed to scientific terms.

\section{Non-Theatrical Performances}

Non-theatrical performances, also referred to as "nondramatic, natural performance scripts,” (Denzin, 1997, p. 99) generate performances that employ a minimum of traditional theatrical convention, such as a story line or dialogue, and may even eschew theatrical "staples" such as sets and costumes. In fact, non-theatrical performances may simply consist of a dramatized reading of interview transcripts that, through their performance, have been transformed into monologues. These monologues may be performed by one or by many individuals. Given the central role of oral presentation in this genre, non-theatrical performances are extremely dependent upon text. Nonetheless, they do represent a first step in moving away from a completely textual interpretation of data, towards a theatrical style that begins to privilege an embodied, theatrical representation of data. Within this genre, the placement of text is 
important as a tool for analysis and knowledge transfer, as sections of narrative may reflect, contrast and "speak" to one another. For example, one piece of text, or monologue, may reflect, highlight or contradict another piece of text, and this interplay between performed pieces of text provides a comment on, or interpretation of, the data. However, while these scripts may draw directly from interview transcripts, they are not realistic vignettes or staged scenes that create a story or narrative between or about the research findings.

This type of production draws from a variety of sources for inspiration, including the world of research and the world of theatre. Goffman made some of the earliest links between social science and performance, first noting the performative nature of day-to-day lived reality (Goffman cited in Denzin, 1997). Similarly, Turner proposed the use of performance and theatre in the study of culture, arguing that the performance of the rituals and ceremonies (including seemingly mundane "performances" of everyday life) of the ethnographic subject allows for a "kinetic” (Turner \& Turner, 1982, p. 34) and holistic understanding of culture and cultural practice. Turner’s (1982) “scripting” of ethnographic field notes is what Denzin and Paget describe as “verbatim theatre” (Denzin, 1997, p. 103; Paget, 1997), a theatrical methodology that uses field notes, interview and focus group transcripts as the scripts.

McCall and Becker (McCall, Becker, \& Meshejian, 1990) have furthered these efforts in their development of a "performance science," or the art of directly scripting social science data. Within their performance science scripts, McCall and Becker (1990) interweave a variety of narratives stemming from their research, which they have scripted into an inter-researcher dialogue. The interpretive aspect of their research occurs not only in what they say to one another about the research, for some of their spoken text features their own comments about their research process and findings, but the way in which they organize and perform the text itself. 
These scripts are then performed in academic settings with each researcher on either end of the stage speaking their part of the dialogue from a podium. The benefit of such performances, McCall and Becker argue, is in their ability to make transparent the process of analysis: "it shows us, talking about what we're doing, constructing interpretations as well as data” (McCall et al., 1990, p. 118)

Non-theatrical performances also may borrow methodologically from the theatre world, in particular from the work of playwright Smith (Smith, 1993; Smith, 1994). Although Smith identifies herself neither as a social scientist nor researcher, elements of her methodology echo methods of performance development in this genre and thus are usefully highlighted. Smith's plays consist of carefully ordered "monologues" taken from interviews she has conducted, primarily in areas of civic tension and social upheaval. For example, Smith interviewed different citizens in Los Angeles during the "Rodney King” riots (Smith, 1993, 1994). Upon completion of the interviews, Smith edited the transcripts into a series of poetic monologues, which she presented in sequence, as a solo act. Smith's immense talent as an actor is, in part, why her plays are such a success; Smith can convincingly take on multiple characters in rapid and fluid succession. However, beyond Smith's remarkable abilities as an actor, the content and arrangement of monologues themselves offer remarkable insight into the social dynamics illuminated by such instances of conflict.

Rosenbaum et al. (2005) have evaluated this type of non-theatrical health research production. Their performance text, In Their Own Words, was created from a series of interviews conducted with patients facing a range of diagnoses. The interviews focused on patient interactions with health care providers, both positive and negative. From these interviews, the researchers selected certain pieces that exemplified patients' narratives about 
their experience of being ill and receiving health care, and, after editing these narratives, they were arranged into poem-like stories (Rosenbaum, Ferguson, \& Herwaldt, 2005). These poems were then used in foundational classes for medical school students: a few students from each tutorial received an interview-poem that was then performed for the larger class. The goal of this project was to humanize patients’ illness narratives, and to capture the emotional dimension of patient experiences, which are often neglected in medical education.

The benefits of transforming data into this type of theatrical presentation are numerous. From a practical standpoint, non-theatrical presentation texts require little theatrical “intervention,” meaning that researchers may choose to transform their data into this type of theatre production without collaboration with theatre practitioners such as a playwright, dramaturg (also called a literary manager), or director, and do not necessarily need to employ theatrical conventions such as props, costumes, sets or elaborate staging. Actors or non-actors can stage non-theatrical performance pieces with little to no rehearsal or memorization of the scripts. From a research perspective, non-theatrical performances may be appealing because they rely heavily on the primary data, directly utilizing pieces of data for the script itself and not "abstracting” or moving away from the data through the process of dramatic interpretation (e.g. scripting semi-fictional scenes based on the research data). Similar to other forms of qualitative research, the interpretive aspect of creating non-theatrical performances involves choosing which pieces of the data to include, and in deciding on the placement of the data in the script.

Turning research into non-theatrical performances also presents drawbacks. While these performances may be easier to stage than more theatrical pieces, the benefits of using more traditional theatrical conventions may also be lost. Because of the focus on spoken text, the interpretive and creative potential of the body in the performance is not fully exercised, and, if 
using non-actors, expressive acting techniques such as subtlety of voice, intonation and physicality may not be used effectively. Further, this type of performance does not allow for the use of metaphor, abstraction or creative staging, all critical tools to engage and move an audience.

Ethnodramas: Interactive and Non-interactive Performances

The second genre of performances used within the interpretation and transfer of research may loosely be grouped in the category of ethnodramas. This term, coined by Turner (1982) and used by health researchers Mienczakowski, Smith and Morgan, refers to research-based theatre that aims to "remain true to the informants who contribute to our research" (Mienczakowski, Smith \& Morgan, 2002, p.34). This entails the creation of "real-life" vignettes that emerge directly from data such as interviews, focus groups or ethnographic notes. Unlike non-theatrical performances, ethnodramas are theatrical; performances feature a variety of characters that engage the audience and each other through monologue and dialogue, and scenes contain elements of dramatic tension. These scenes stand in opposition to dramatic interpretation that occurs in the non-theatrical performance genre, where simple narrative exposition of nondialogic pieces of text constitutes the analysis and performance.

However, like non-theatrical performances, ethnodramas aim to communicate research findings and to remain ardently faithful to primary research subjects and the veracity of the data. Thus, performativity and theatricality may take a backseat to verisimilitude and realism. As Mienczakowski et al. (2002) write:

Gone is the primacy of 'artistry.' Individual performance is of secondary consequence here - this form of performance is about informants... what motivates most of these ethnodrama audiences to debate is the performance's content and relations to real health experiences, not its style" (p. 34, emphasis added) 
In their development of a research-based dramatic production about self-expression by persons with severe Alzheimer's disease, Kontos and Naglie (2006) similarly felt it necessary to remain faithful to realistic, "in life” scenes, such as those that were actually observed in Kontos' ethnographic research on an Alzheimer's support unit (Kontos, 2004; Kontos 2006; Kontos \& Naglie 2006), precisely because her observations so powerfully capture how selfhood continues to be expressed through bodily habits, gestures and actions, irrespective of cognitive impairment (Kontos and Naglie, in press).

Given the proximity of these scenes to "real life" scenarios, these performances may be more open to interactivity and in-the-moment modification of the performance by both audience members and performers (Mienczakowski, 1997). Much of the interactive work within this genre draws explicitly from the work of Brazilian theatre practitioner Boal's (1985) methodology, Forum Theatre, or Theatre of the Oppressed. This theatrical form aims to aid marginalized and disenfranchised people in transforming and transcending social oppressions through role-play, using scripted texts as a basis for improvisations (Boal, 1985). In particular, Boal's Forum Theatre methodology allows audience members, or "spect-actors", to engage with a scene relevant to their own personal situation, and to intervene in pre-chosen moments during the performance that dramatize instances of oppression and marginalization. As such, audience members and actors alike may improvise multiple ways of understanding and reacting to a difficult situation. In this way the forum theatre space is a "safe" way for oppressed people to both critically reflect upon, and envision alternatives to the social conditions creating their marginalization.

Several examples of ethnodramas have been published, which provide insight into this particular genre. Mienczakowski (1999) and his research team (Rolfe, Mienczakowski, \& 
Morgan, 1995) have created at least two such texts: Synching Out Loud, a play that depicted the struggles of people living with schizophrenia, and Busting, which captured the experiences of alcoholics who have undergone detoxification within an institution. Both plays are based upon ethnographic studies and were performed by student actors and student nurses for audiences comprised of research informants, students, and health care professionals in the field. When performed, these plays were "opened" to the audience for Forum Theatre interventions, allowing audience members to intervene in the drama by coming on stage at chosen moments of the drama (generally moments of tension, or that highlighted instances of oppression or marginalization) and to re-imagine and re-make these scenes through facilitated improvisation with the actors (Mienczakowski, 1999; Rolfe et al.., 1995).

Also drawing from Forum Theatre techniques, researchers Brown and Gillespie (1997) provide another illuminating example of interactive ethnodrama. Their work is aimed at educating and aiding graduate students in occupational therapy to grapple with complex bioethical issues faced within a clinical setting. Lengthy in-class discussions led to the scripting of "real-life" scenes, which were performed by the students themselves for one another. While health care providers may not experience the same types of difficulties originally faced by Boal and the Brazilian "spect-actors" with whom he worked, the tremendous strain from increased levels of bureaucratization and its effects on clinical decision making comprise a new form of marginalization and "moral distress" (Brown and Gillespie 1997, p. 3-4) for many health care providers, thus making it fertile ground for intervention using Forum Theatre.

A similar example of interactive ethnodrama was used for the translation and dissemination of primary health research findings by the South African Stroke Prevention Initiative, which has used Boalian theatre techniques as a method of turning anthropological 
research into an interactive tool for social change (Stuttaford, Bryanston, Hundt, Connor, Thorogood, \& Tollman, 2006). In this case, researchers presented an interactive play based on anthropological data about cardiovascular disease, in particular stroke, to the community in which the study took place, using the play as both an educational device to help audience members to identify signs of stroke and respond accordingly, and as means of collective social action. Through the play's presentation, and subsequent theatrical interventions and discussions, the community identified issues and barriers impeding the prevention of stroke and care of stroke victims, and also strategies aimed at improving local health care facilities and services and integrating local care practices with Western forms of health care.

The interactive nature of these performances serves pedagogical and research purposes. This genre of performances allows audience members to learn by doing, but, also when performed for audiences that include research informants, this interaction strengthens the validity of the research/performance, since the research "subjects" can give direct voice to their own experiences and reflections as depicted on stage (Mienczakowski, 1999). In other words, informants themselves are present and actively engaged, and thus can correct, add, alter and reaffirm research findings through theatrical intervention.

Staging "real-life” may appear straightforward since it requires less technical theatrical skill than to dramatize or fictionalize research findings. However, to produce "staged real-life" requires proficiency and practice from writers and actors alike (Kontos \& Naglie, 2006). Furthermore, experience is necessary to run interactive performances, particularly if the audience has a tremendous personal stake in the material. This type of interaction is volatile (Rolfe et al., 1995), and, while it can generate enormous insight and unequaled opportunities for learning and 
reflection, it can trigger unexpected emotions and reactions that may require skilled management.

As noted earlier, not all work in this genre is interactive. Kontos and Naglie (2006) provide an example of a non-interactive ethnodrama. Expressions of Personhood in Alzheimer's is a production that is based on Kontos' ethnographic research on personhood in Alzheimer's disease (2004; Kontos, 2006). She explored how personhood is expressed by residents of an Alzheimer's support unit through their bodily movements and gestures - captured in the theoretical notion of embodied selfhood (Kontos, 2004; Kontos 2006; Kontos \& Naglie, 2006) even when cognitive faculties are severely impaired. The production consists of five separate vignettes, all taken directly from Kontos’ ethnographic notes and staged by veteran playwright Vrenia Ivonoffski of Toronto’s Act II Studio. Each vignette features prominent examples of embodied selfhood such as a severely cognitively impaired female resident who demonstrated her awareness and concern for her appearance by pulling out a string of pearls from underneath her bib so that they could be seen by other residents seated at her dining table. Drama facilitates the recovery of the experiential immediacy of the body present in the original data gathering setting, which, in the case of this dramatic production, permits a powerful demonstration of how selfhood is manifested in gesture and action (Kontos \& Naglie, 2006).

Expressions of Personhood in Alzheimer's was performed at the outset of focus groups with health care practitioners for the purpose of exploring with them the notion of embodied selfhood and how it can improve person-centred dementia care. It was not an interactive performance text as there was no participation by the focus group participants in the production itself. However it did serve as a springboard for discussion about embodied selfhood in the 
context of dementia care and thus the participants did have the opportunity to reflect upon the production in the post-performance focus group discussions.

\section{Theatrical Research-Based Performance}

A third genre of performance, what we term theatrical research-based performance, is similar to a theatrical category that Denzin (1997) terms “improvised ethnodrama," which he describes as a genre that "fundamentally transform[s] [the] experience of text," and stands in opposition to ethnodramas, which "maintain a deeper commitment to [the site of research] and its 'original' meanings.” (p. 100) The genre of theatrical research-based performances is also consistent with Saldana’s description of “ethnotheatre.” As Saldana (2005) writes:

Ethnotheatre employs the traditional craft and artistic techniques of theatre production to mount for an audience a live performance event of research participants' experiences and/or the researcher's interpretations of data...Simply put, this is preparatory fieldwork for theatrical production work. (emphasis added, p. 1-2)

As such, these performances are informed by the research process, but do not strictly adhere to the data as script. For example, Gray and Sinding note that in their production, Handle With Care?, "the knowledge foregrounded in [the] script development process emerged from, but was not contained by, what was said in the transcripts or how it was said” (Gray \& Sinding, 2002, p. 19).

It is important to note here that the methods used in this performance genre are not simply a means to create different types of performances, but rather to create performances with different instrumental goals. While the aims of the two above mentioned genres may be to transfer knowledge through a strict adherence to data for the purposes of teaching, health promotion or policy development, the goals of this genre may be more implicit. Theatrical research-based performances may instead take artistry or an exploration of artistic form as a primary goal. While the end result of both types of production may be the communication of 
health research in an engaging and moving way, it is important to note these foundational differences at the outset.

Thus, performances in this genre may move away from realism and verisimilitude towards the aesthetic and creative power of theatre as an interpretive, analytic tool. Denzin (1997), who has made a strong case for the use of performance for the analysis and interpretation of social science research, cites the ability of performance to question and deconstruct the notion of a singular "truth" by recounting narratives from multiple perspectives and angles, thus contesting the linear, naturalistic form of traditional textual renderings of research findings, particularly from qualitative research. Denzin (1997) places greater value on performances that are fictional, theatrical and stylized, as opposed to those that are based on realism and verisimilitude. By removing these performances from the strictures of verisimilitude, Denzin (1997) argues that this type of theatre creates a space for both interpretation and "cultural critique” (p. 100).

Similarly, Paget (1993), whose research regarding “misconstructed moments” between doctors and patients in relation to cancer was transformed into a theatrical performance text by dramatist Emilie Beck, notes that, just as the act of academic writing is interpretive, so too is the process of making data theatrical. Paget (1993) cautions not to see the academic text as the only truthful interpretation and notes that the live, multi-dimensional performance text could say much more than the academic text, including the ability to both capture and comment on the “speakers' miens and intentions” (p. 31). That is, the act of theatricalizing data allows for a whole new form of interpretation and analysis, one that uses theatre's fantastic, imaginative possibilities. 
Thus within Beck and Paget’s The Work of Talk (1993), many theatrical “liberties” are taken with the data. For example, cancer, in this piece, is personified as an actual character in the play who is marked by a very specific costume, and specific role: "throughout the performance, Cancer pays close attention to the patient. She dresses her up, coming by at one point to apply makeup and at another to give her a chocolate. The patient belongs to Cancer.” (Paget, 1993, p. 28, emphasis added) Here, Cancer is being used as a metaphor; she is clearly not a "real" person who demands attention from the patient. However, the emotional impact of this metaphoric presentation of cancer as a character may be far more significant than could be evoked by written text or verbatim enactments of data that are more realistic.

Gray et al. $(2000,2003)$ provide two important examples of work within the theatrical performance genre. This research team, which includes playwright and theatre practitioner Vrenia Ivonoffski have created two plays: Handle With Care?, which dramatizes women's struggles and experiences with metastatic breast cancer; and No Big Deal?, which examines men’s experiences of prostate cancer (Gray, Ivonoffski, \& Sinding, 2002; Gray et al., 2003; Gray et al., 2000; Gray \& Sinding, 2002). These productions were created and acted by ensemble casts that included amateur actors, researchers and cancer survivors. Both productions have been toured across North America with tremendous success, and have been performed for researchers, medical practitioners and general community members (Gray et al., 2003). While Gray et al. $(2000,2003)$ certainly considered working in the ethnodramatic style utilized by Mienczakowski, which draws predominantly from research data for the basis of theatrical production, these research-team-cum-acting-troupe chose instead not to rely solely on formallygathered data. Instead, they chose to utilize the cast's personal experiences, thoughts, and reflections regarding the experience of cancer, as well as the group dynamics and emotional 
reactions to the data as a springboard for dramatic improvisation and creation. As Gray and Sinding write: "A drama that emerges from such a process is very much a negotiated settlement, a collective achievement.” (Gray \& Sinding, 2002, p. 19)

As such, the creation of these pieces was "messier" (Gray and Sinding, 2002) and less linear than the creation of performance texts in other genres. Handle With Care?, for example, emerged from many months of collective exploration of metastatic breast cancer. As noted, the cast consisted of researchers (including both Gray and Sinding), actors, women living with metastatic breast cancer, and others involved in the wider breast cancer community (Gray \& Sinding, 2002, p.1). The exploration process included not only in-depth analysis and investigation of transcripts from interviews and focus groups with breast cancer survivors (or women living with breast cancer), and oncologists, but also intensive group improvisations, conversations, and interpersonal exchanges within the group. From this highly collective and personal process, Ivonoffski gathered images, scenes, ideas, characters, and pieces of dialogue, which she wove into a loose and preliminary script. This script was “reviewed and reworked” by the group, in order to more powerfully convey the emotion of the experiences of women with metastatic breast cancer (Gray et al., 2000, p.139). With a finished script in place, rehearsals, and eventual performances ensued.

Like Paget's work, the pieces that emerged from this creative process are not intended to portray an actual reality. For example, Handle With Care? features a scene in which a character suffering from metastatic breast cancer is literally pushed from one end of the stage to another by friends and family as she is bombarded by their unhelpful, unsolicited advice (Gray et al., 2000 p. 140). Similarly, No Big Deal? opens with a vignette of a married couple in a war zone, heading into a battle - an image evocative of the feelings experienced by men and their partners 
as they begin to engage with the medical system after having been diagnosed with prostate cancer (Gray et al., 2003, p. 224). Again, while these scenes are not intended as actual portrayals of lived reality, they do “[provide] a more direct pathway to the lived 'truth' of their experiences than a compilation of verbal statements ever could have” (Gray et al., 2000, p.140).

Mitchell et al. (2006) provide a more recent example of work in this genre. Their play, I'm Still Here, draws from research regarding the "meanings, the joys and sorrows, the losses and gains, the concerns and hopes, and...the importance of relationships" in the lives of people suffering from dementia (2006, p.198). These researchers employed the skills of playwright and theatre practitioner Ivonoffski to weave together not only primary research data, but ideas stemming from discussion, personal experience, improvisations about the research material, secondary data explorations and both group and personal reflection. Through this process Ivonoffski struggled with both emotional and ethical questions regarding the enactment of painful personal moments uncovered through the research process. Ivonoffski's struggle revolved around how to sensitively stage these deeply personal moments knowing that her audience would be comprised of both persons with dementia and their families. As in other examples of work in this genre discussed already, the multifaceted approach to the creation of the play, including a departure from the "facts" of the research data, fostered a very real sense of emotional truth for its audiences.

While many research-based theatre productions arise from the collaborative efforts of researchers, participants and actors, such productions need not be collective creations. Bioethicist Nisker (2005), who aimed to use theatre as a "tool for public engagement in policy development regarding genetic testing,” (p. ii) acted as both researcher and playwright. Gathering data from multiple sources, including key informant interviews and both scholarly and 
popular press, Nisker designed his play, Sarah's Daughters, less as a way to impart primary research findings, but rather as a means to test theatre as an instrument for eliciting public opinion and input regarding a particular area of health policy development. As such, Nisker's play is a fictional narrative that draws from his research. The play touches upon some of the painful and pertinent socio-emotional issues and dilemmas that Nisker felt were necessary to engage audiences in a fruitful and informed discussion about policy development in the area of genetic testing.

Finally, research-based theatrical works do not necessarily need to include researchers themselves, and can be devised either by artists, or theatre troupes, or by health professionals themselves. In one such example, the managing staff at a British community health group decided to use drama to bring to life elements of community research about the needs of individuals with dementia and their families. The drama itself was created by a troupe of actors/dramatists (and not researchers) who specialize in drama-based learning projects. The research was completed prior to the drama's inception and an acting troupe drew from the research what they felt they needed for the creation of an informative, yet fictionalized, performance. The drama was presented to numerous stakeholders within the health care community, many of whom felt their practice had changed as a result of having seen the drama (McKay \& Bright, 2005).

The tension between scientific and artistic renditions or interpretations of data may present a real difficulty in the creation of theatricalized performances. Saldana (2003) notes that “a researcher’s criteria for excellent ethnography in article or book formats do not always harmonize with an artist’s criteria for excellent theatre.” (p. 220) Given the structural difference between theatre's primary goal (to entertain) and the primary goals of research (to extract and 
convey experiences of their research participants), ethnotheatre is faced with the difficult task of reconciling these disparities in order to create a performance that is "aesthetically sound, intellectually rich, and emotionally evocative.” (Saldana 2003, p. 220) Of course, this may be more easily written than enacted. To take on this type of project necessitates working in a highly flexible, and interdisciplinary manner, drawing as strongly from the arts, and from artistic practitioners, as from the sciences and researchers. Further, the artistic practitioners must understand the "needs" of the data, while the researchers must be open to theatrical interpretations, where the "performances [make] fantastic some of the facts in order to state them.” (Paget, 1993, p. 32)

Fictional Theatrical Performance

The fourth, and final genre addressed in this article is that of Fictional Theatrical Performance. This genre encompasses works that are performed for the purposes of health care education that are not based on research. This includes "mainstream" artistic pieces, such as dramatic texts (plays), poetry, fiction, as well as pieces created by health professionals for the education or engagement of other health professionals. The process of creating these works may either be that of a single author, or created by a group of authors. The works themselves may be realistic or imaginative but fictional. They may be professionally staged and performed by actors, or presented by amateurs in a non-theatrical setting or venue, such as a classroom or hospital.

For example, researchers at the University of California Los Angeles medical school devised a unique program to engage doctors-in-training in a more emotionally connected learning process than is provided in traditional medical training. Using Margaret Edson’s Pulitzer prize-winning play Wit, which follows the illness and demise of a cancer patient, 
researchers Lorenz, Steckart and Rosenfeld (2003) began the Wit Educational Initiative (WEI). This organizational and fund-raising initiative allowed medical schools across North America to be linked with productions of Wit for their students, which included large, facilitated “postperformance discussions” with cast members and local faculty using a pre-developed discussion guidebook. The aim of this initiative was to "promote humanism, empathy, and selfreflection in the care that medical trainees provide to dying persons” (Lorenz et al., 2004, p. 482). Through this program, 32 sites mounted a WEI-supported production of the play, performing for a total audience of 2,582 (Lorenz et al., 2004).

While not as large an initiative, medical researchers and staff at University of California Irvine have identified a similar lack of empathy in doctors-in-training, and have turned to theatre as a means of humanizing medical education. They mounted two productions created by local professional actors/patients. One performance centred on the personal reflections of an HIV/AIDS patient, who transformed his story into song and narrative. The other followed the journey of an ovarian cancer survivor (Shapiro \& Hunt, 2003). These productions were performed for mixed audiences that included doctors, family members and patients themselves.

A third use of artist-created Fictional Theatrical Performance comes in the form of Readers Theatre. Readers Theatre is an "aesthetic strategy...a scripted, formalized storytelling experience," which "involves the oral presentation of text, be it prose or poetry" (Pardue, 2004, p. 58). In this particular instance, pieces of fictional narrative (short stories and poems) were chosen to aid nurses-in-training to "connect to the deeper [emotional and spiritual] meaning of a situation” (Pardue, 2004, p. 58). These pieces were then presented as staged readings by members of the nursing faculty at the University of New England to nursing students at different stages of their training. Perhaps more analogous to radio drama than stage performance, these 
productions required no theatrical intervention (e.g. staging, props, costumes, et cetera). The "emotional truth" arose from the strength and artistic integrity of the chosen pieces.

The use of fictionalized theatrical performances for the purposes of knowledge transfer has both benefits and limitations. Because these performances are not drawing from original research, the process of their creation is unconstrained by data and the rigours of the research process. Thus, validity, realism and empirical fact may take a backseat to emotional truth and dramatic style and flow. However, these facets may also present a drawback. As Gray et al. (2000) remark, “[w]hilst theatre can certainly be profound without a research base, audiences that are oriented towards empiricism appear to be more receptive and comfortable with 'data' that have been accumulated within traditions of inquiry that they respect” (p. 142). Critical questions regarding the nature of truth, fact and knowledge arise when works of fiction are used to inform real-life practices.

\section{Evaluation and Impact of Theatre}

In this section we explore the efficacy of using theatre for the purposes of data analysis and knowledge transfer, and critically examine potential approaches to the evaluation of such endeavours. As noted earlier, all studies included in this article have evaluated their work in some fashion, the results of which are collected in Table 2 . What this summary most clearly illuminates is the lack of coherence between styles of appraisal. Broadly speaking, three major methodologies have been used including unstructured forms of feedback (e.g. reflective journals from students and informal discussions), structured but open-ended questionnaires, and highly structured, quantitative surveys. Further, these evaluations concentrate on two major areas of analysis: did participants enjoy the production, and did participants learn about the presented topic and change their behaviour or attitude as a result of attending the performance? 
While the results of these evaluations are uniformly positive, gaps in the assessment process are noticeable and raise questions regarding how best to appraise the impact of similar creative undertakings. For example, none of the studies have managed to concretely or objectively capture long-term effects of theatre as a learning or dissemination intervention in terms of attitude, behaviour or practice. Similarly, while many studies explored audience enjoyment and satisfaction, the aesthetic quality of the productions has not been examined. Further, few sustained quantitative inquiries regarding research-based theatre have been conducted. In one study (Lorenz et al., 2004), participants were asked to rate the efficacy of theatrical production in relation to more traditional forms of knowledge translation, and in two others (Mitchell et al., 2006; Shapiro and Hunt, 2003), participants were asked to rate their responses to a variety of items on a Likert-scale evaluation following the show. However there have been no randomized, controlled studies regarding the effects of theatrical intervention to date. It is important to note that the limitations of these evaluations are not a function of poor design or execution, but rather stem from the fact that the evaluation of artistic or creative intervention is, by nature, remarkably difficult, and thus requires further examination. Difficulties in the evaluation process begin with identifying what one wishes to measure. As evidenced by the studies outlined above, there are two areas of concentration: content and aesthetics. These however, are deceptively simple. First, does one treat the categories of "content" and "aesthetics" as separate entities, thereby framing the evaluation as a kind of multivariate regression analysis; or are they inextricably linked, content informing aesthetics, and aesthetics dictating the impact or impression of content? Second, how does one measure the behavioural or attitudinal changes experienced by a health care provider over time, after he or she witnesses a research-based theatre production? Third, how might one measure the 
effects of a production that is factually correct and true to the original data, but aesthetically unpleasing? In other words, how might the effects of theatre be measured or accounted for, separate from the production's content? How are audience satisfaction and production aesthetics linked, and how might this link be evaluated?

Deciding upon what form the evaluation of such productions must take is equally challenging. Open-ended, unstructured evaluations may allow for deeper levels of personal reflection, emotional exploration, and insight into the process of creative engagement. However, it is difficult to fully determine impact or to generalize conclusions from these types of evaluations, and thus may garner criticism from those wishing to understand theatre's reliability as a research method. Conversely, survey-type evaluations allow for broad examinations of general audience sentiment, but miss profoundly individual reactions to the production, which may inform our understanding of how theatre-based education and research dissemination operates at a personal and interpersonal level. However, large-scale quantitative studies may also inform an understanding of the levels of impact generated by research-based theatre. For example, a randomized case-control study, a form of evaluation currently missing from the literature, might lead us toward an understanding of not only how research-based theatre operates, but how it compares to other forms of knowledge translation. While the studies included in our literature review have all made worthy and important contributions to our understanding of the virtues of health-based research theatre, we have identified the challenges of evaluating arts-based projects, which underscore the need for further development in this area.

\section{Conclusion}

Theatre holds great promise in the world of education and health research translation. By engaging audiences on a cognitive and emotional level, and by using both verbal and non-verbal 
(or physical) forms of communication, theatre has the potential to enhance health care practitioners' understanding of the complex emotional, interpersonal and psychological dynamics that arise in medical practice, many of which are difficult to fully convey in more traditional forms of dissemination (e.g. scientific articles). Through theatre, practitioners not only can acquire new insights regarding research in areas of health science, but can have their own professional experiences and best practices reinforced. Further, projects that use interactive theatre provide a unique means of allowing practitioners, informal caregivers and patients alike the opportunity to "rehearse" reality, and to validate research findings.

With so few evaluation studies upon which to draw, important questions regarding theatre's use in health research remain. For example, it is unclear what kind of research is most suited to dramatic treatment: is theatre a tool best utilized by researchers in social science and psychology, or might "harder" sciences also benefit from the use of theatre in research translation? How might we measure theatre's efficacy against its potential disadvantages, such as the costs incurred by some theatrical endeavours, which far outweigh the costs of simply publishing a study? Further, these studies do not provide conclusive evidence regarding which genre is most amenable to the translation of research findings, or, more helpfully, what different effects might each genre tend to elicit in terms of long-term learning and change? Finally, more work is needed in the area of evaluation itself: what type of evaluation best fits theatre as a medium for knowledge translation? Given the rich potential of theatre to expand the horizons of health research, these areas of inquiry are suggestive of the kinds of research needed. 


\section{References}

Babbie, E. \& Benaquisto, L. (2002). Fundamentals of social research. Scarborough, Ontario: Thomson Nelson.

Boal, A. (1985). Theatre of the Oppressed. New York: Theatre Communications Group.

Brown, K., \& Gillespie, D. (1997). "We become brave by doing brave acts": Teaching moral courage through the theatre of the oppressed. Literature and Medicine, 16(1), 108-120.

Denzin, N. (1997). Interpretive ethnography: Ethnographic practices for the 21st century. London: Sage Publications.

Gray, R., Fitch, M., Labrecque, M., \& Greenberg, M. (2003). Reactions of health professionals to a research-based theatre production. Journal of Cancer Education, 18(4), 223-224, 225, 226, 227, 228, 229.

Gray, R., Ivonoffski, V., \& Sinding, C. (2002). Making a mess and spreading it around: Articulation of an approach to research-based theatre. In A. Bochner, \& C. Ellis (Eds.), Ethnographically speaking (pp. 57-75). Walnut Creek, CA: AltaMira Press.

Gray, R., \& Sinding, C. (2002). Standing Ovation: Performing Social Science Research About Cancer. Walnut Creek CA: AltaMira Press.

Gray, R., Sinding, C., Ivonoffski, V., Fitch, M., Hampson, A., \& Greenberg, M. (2000). The use of research-based theatre in a project related to metastatic breast cancer. Health Expectations, 3(2), 137-144.

Kontos, P. (2006). Embodied selfhood: An ethnographic exploration of Alzheimer's disease. In L. Cohen, \& A. Leibing (Eds.), Thinking about dementia: Culture, loss, and the anthropology of senility. (pp. 195-217). Cambridge: Cambridge University Press.

Kontos, P. (2004). Ethnographic reflections on selfhood, embodiment and Alzheimer's disease. Aging and Society, 24, 829-849.

Kontos, P., \& Naglie, G. (2006). 'Expressions of personhood in Alzheimer's: Moving from ethnographic text to performing ethnography. Qualitative Research, 6(3), 301-317.

Kontos, P., \& Naglie, G. (In Press). ' Expressions of personhood in Alzheimer’s disease’: an evaluation of research-based theatre as a pedagogical tool. Qualitative Health Research.

Lorenz, K. A., Steckart, M. J., \& Rosenfeld, K. E. (2004). End-of-life education using the dramatic arts: The wit educational initiative. Academic Medicine, 79(5), 481-486.

McCall, M., Becker, H., \& Meshejian, P. (1990). Performance science. Social Problems, 37(1), 117-132. 
McKay, M., \& Bright, S. (2005). Dementia care: Learning through drama. Practice Development in Health Care, 4(1), 18-236.

Mienczakowski, J. (1999). Ethnography in the hands of participants: Tools of dramatic discovery. Studies in Educational Ethnography, 28, 145-161.

Mienczakowski, J. (1997). Theatre of change. Research in Drama Education, 2(2), 159-172.

Mienczakowski, J. (1995). The theater of ethnography: The reconstruction of ethnography into theater with emancipatory potential. Qualitative Inquiry, 1(3), 360-375.

Mienczakowski, J., Smith, L., \& Morgan, S. (2002). Seeing words - hearing feelings: Ethnodrama and the performance of data. In C. Bagley, \& M. Cancienne (Eds.), Dancing the data (pp. 35). New York: Peter Lang Publishing, Inc.

Mitchell, G., Jonas-Simpson, C. \& Ivonoffski, V. (2006) Research-based theatre: The making of I'm Still Here! Nursing Science Quarterly, 19(3), 198-206.

Nisker, J. (2005) An examination of theatre as a tool for public engagement in policy development regarding genetic testing. Unpublished doctoral thesis, University of Toronto, Toronto, Ontario, Canada.

Paget, D. (1997). Verbatim theatre: Oral history and documentary techniques. New Theatre Quarterly, 12, 317-336.

Paget, M. (1993). In DeVault M. (Ed.), A complex sorrow: Reflections on cancer and an abbreviated life. Philadephia: Temple University Press.

Pardue, K. T. (2004). Introducing readers theater! A strategy to foster aesthetic knowing in nursing. Nurse educator, 29(2), 58-62.

Rolfe, A., Mienczakowski, J., \& Morgan, S. (1995). A dramatic experience in mental health nursing education. Nurse Education Today, 15(3), 224-227.

Rosenbaum, M., Ferguson, K., \& Herwaldt, L. (2005). In their own words: Presenting the patient's perspective using research-based theatre. Medical Education, 39, 622-631.

Saldana, J. (2003). Dramatizing data: A primer. Qualitative Inquiry, 9(2), 218-236.

Saldana, J. (Ed.). (2005). Ethnodrama: An anthology of reality theatre. Walnut Creek, CA: AltaMira Press.

Shapiro, J. \& Hunt, L. (2003). All the world's a stage: the use of theatrical performance in medical education. Medical Education, 37, 922-927.

Smith, A. D. (1994). Twilight, Los Angeles, 1992. New York: Doubleday.

Smith, A. D. (1993). Fires In The Mirror. New York: Doubleday. 
Stuttaford, M., Bryanston, C., Hundt, G. L., Connor, M., Thorogood, M. \& Tollman, S. (2006). Use of applied theatre in health research dissemination and data validation: a pilot study from South Africa. health, 10(1), 31-45.

Turner, V. (1982). From Ritual to Theatre: The Human Seriousness of Play. New York: Performing Arts Journal Publications.

Turner, V., \& Turner, E. (1982). Performing ethnography. The Drama Review, 26 (2), 33-50. 
Table 1: Summary of Theatre-Based Health Research Project Evaluations

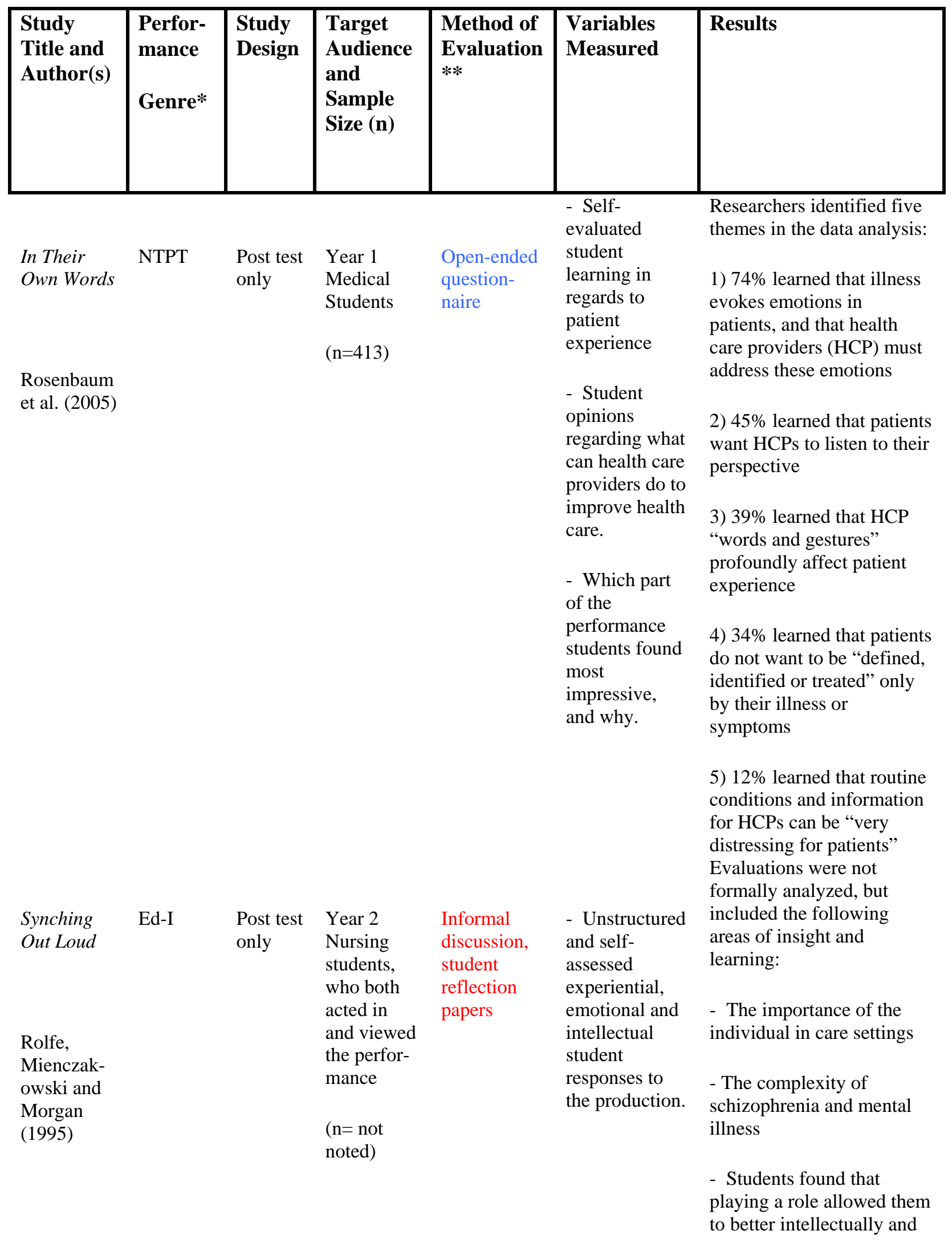




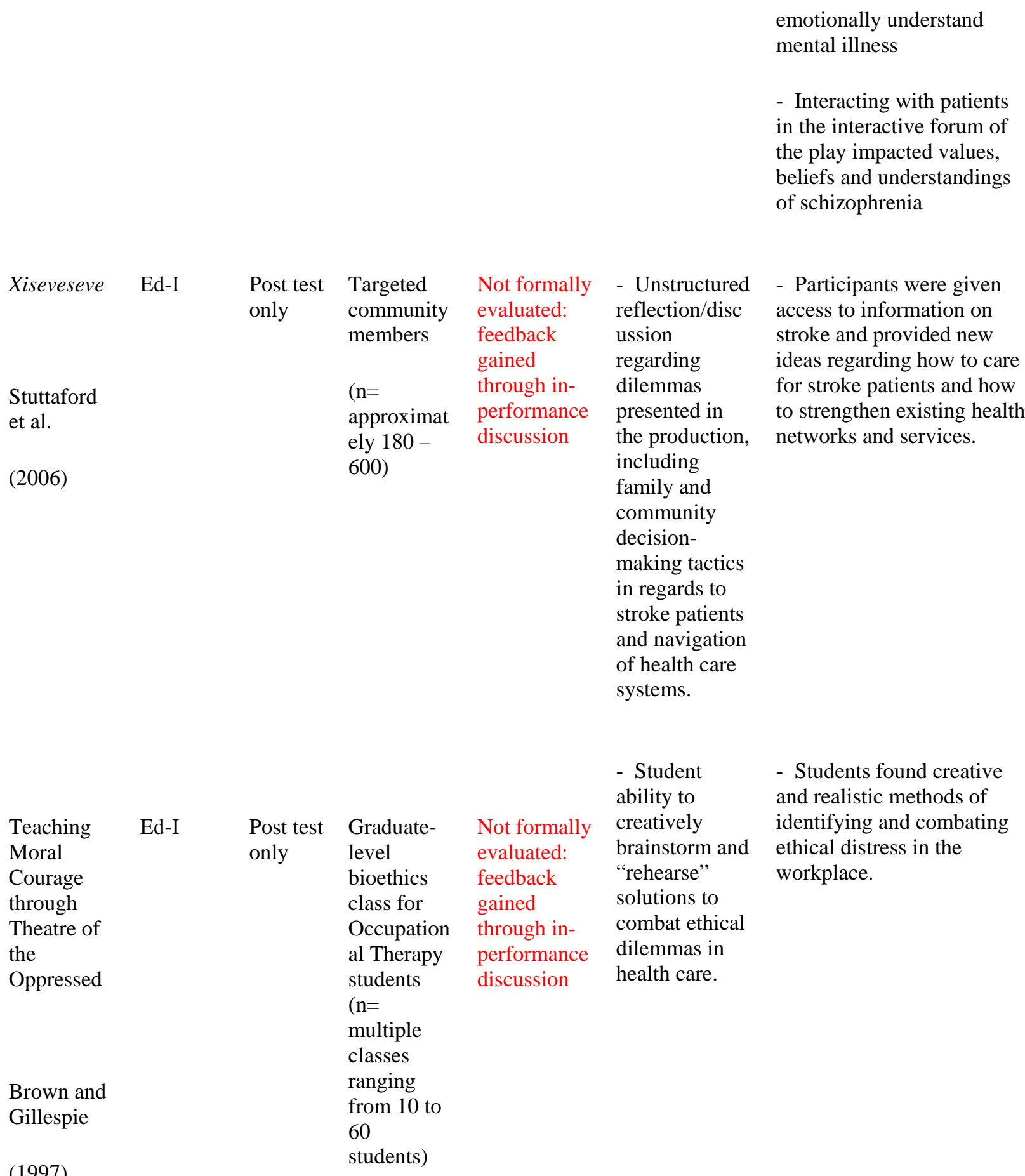

Expressions
of
Personhood Ed-NI
In
Alzheimer's

\author{
This analysis \\ took place in \\ two parts: 1) \\ a closed- \\ ended, 5-point \\ Likert-scale

\section{Analysis of the data revealed the following results:} \\ 1) $97.6 \%$ of respondents \\ agreed or strongly agreed \\ that the play reminded them
}


Kontos and

Naglie

(In Press)

I'm Still

Here

Mitchell, Jonas-

\section{questionnair}

e questionnaire that asked audience members to rate the degree to which the play raised awareness regarding person-centred care of Alzheimer's patients; and 2) an openended focus group forum prompting audience members to reflect upon

what was most and least interesting about the play of their own experiences

from clinical practice;

2) $83.3 \%$ agreed or strongly agreed that the play raised awareness of the different ways that patients with Alzheimer's disease express themselves;

3) $92.2 \%$ agreed or strongly agreed that the play raised awareness of the ways in which they interact with patients with Alzheimer's disease;

4) $100 \%$ agreed or strongly agreed that the play raised awareness of the need for staff to recognize and respond positively to patients' bodily movements and gestures in the context of dementia care

5) $97.6 \%$ agreed or strongly agreed that using researchbased drama is an effective way of educating staff about caring for patients with Alzheimer's disease.

Additionally, analysis of the focus group data revealed that the play allowed practitioners to recognized instances of embodied personhood, and to appreciate the importance of ritual and ceremony for Alzheimer's patients.

- Did audience Analysis of the data members gain a new or enhanced revealed the following ( $M$ $=$ mean scores of the 7 point Likert scale): understanding of the patient experience of dementia?

- Did audience
- The play greatly enhanced understanding of the patient experience of dementia $(\mathrm{M}=6.2)$ 
Simpson,

and

Ivonoffski

(2006)

$\begin{array}{ll} & \text { experience of } \\ & \text { family } \\ \text { members in } \\ \text { regards to } \\ \text { dementia? }\end{array}$

- Did audience

Handle with Care?

TRB

$\begin{array}{ll}\begin{array}{l}\text { Post test } \\ \text { only }\end{array} & \begin{array}{l}\text { Practicing } \\ \text { health } \\ \text { professiona }\end{array} \\ & \begin{array}{l}\text { ls, general } \\ \text { public }\end{array} \\ & \\ & (\mathrm{n}=507) ; \\ & \\ & \text { health } \\ \text { professiona } & \\ & \text { ls only } \\ & (\mathrm{n}=249)\end{array}$

Open and

closed-

ended

questionnair

e
Gray, et al.
- Did audience members learn

something new

about

themselves?

- Did audience members feel

that their

practice woul

change

because of the

performance? members feel

that learning

through theatre

helped them

better

remember, understand or

enjoy research findings?

- Did audience members find this experience worthwhile?

- Did audience members enjoy

$\begin{array}{ll}\begin{array}{l}\text { members gain } \\ \text { a new or } \\ \text { enhanced }\end{array} & \begin{array}{l}\text { - The place greatly } \\ \text { enhanced understanding of } \\ \text { family members' } \\ \text { understanding } \\ \text { of the } \\ \text { experience of } \\ \text { family }\end{array} \\ \begin{array}{l}\text { members in } \\ \text { regards to } \\ \text { dementia? }\end{array} & \begin{array}{l}\text { - Audience members felt } \\ \text { that their practice would } \\ \text { change on account of the } \\ \text { play }(\mathrm{M}=6.1)\end{array}\end{array}$

- Audience members felt that the use of drama helped them better understand and remember research findings $(\mathrm{M}=6.4)$

- Audience members felt strongly that this was a worthwhile experience ( $\mathrm{M}$ $=6.9$ )

and benefit

from the production?

- $100 \%$ of both audience members enjoyed and benefited from the production.

- 99\% of mixed audiences - Did audience and $100 \%$ of health members find professional audiences felt the production that the production was truthful? truthful (or valid)

- Did the - - 99\% believed that the audience research component of the members feel play made it more "true to that the 


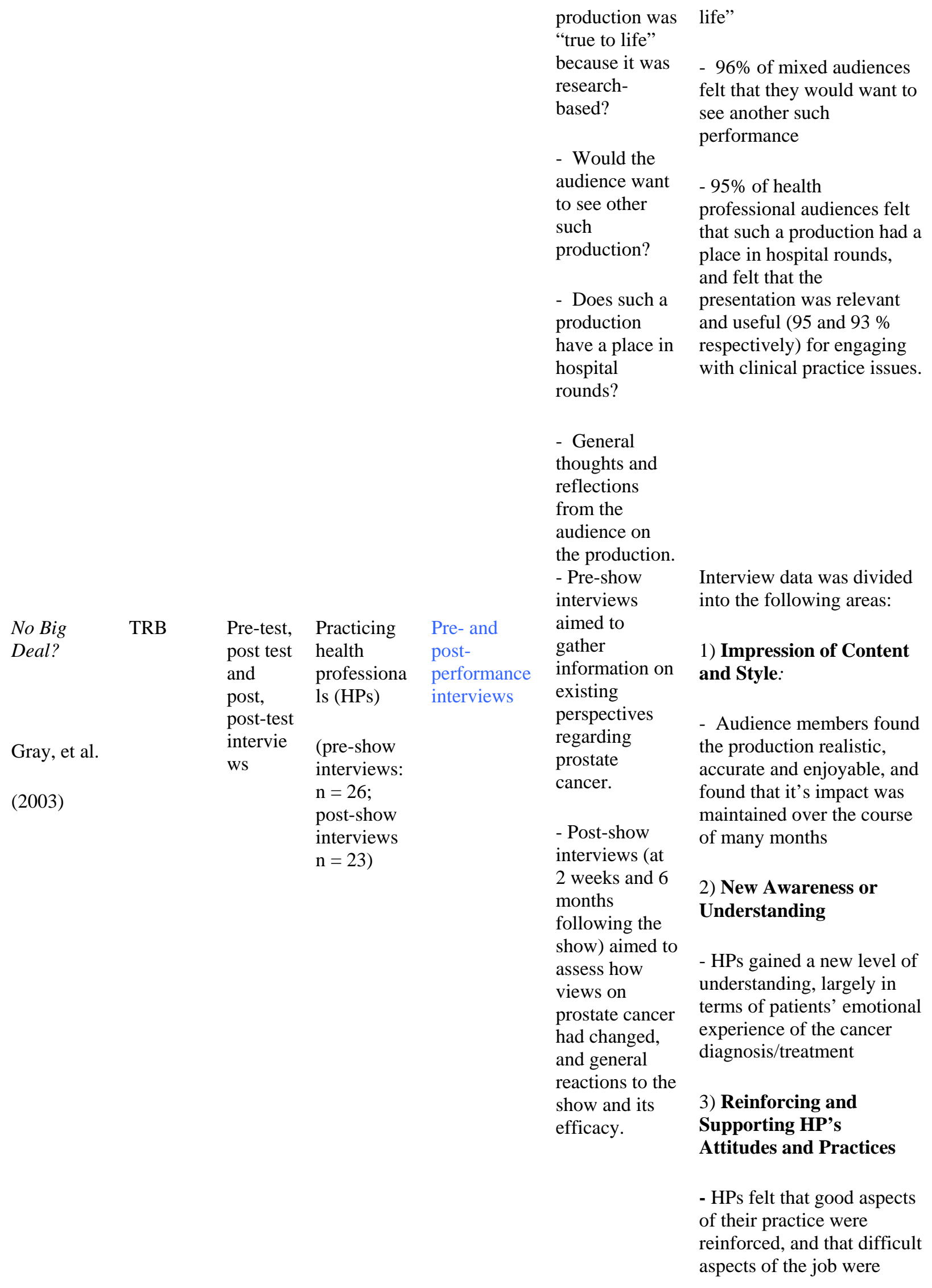


validated as such.

\section{4) Shared humanity between HP and Patient}

- HPs felt that the play helped bridge some of the interpersonal patient/HP distance that occurs, and allowed for a shared sense of humanity with their patients.

\section{5) Implications for Practice}

- HPs took valuable, individual lessons with them in terms of bettering aspects of practice, such as including spouses in care decisions, and recognizing the emotional reality of (unemotive) patients

\section{6) Value of Research- Based Theatre}

- All of the interviewees noted the value of RBT, and its potential as a learning tool, although some felt that not all issues would be suitable for dramatic treatment.

$\begin{array}{llll}\begin{array}{l}\text { Wit Educat- } \\ \text { ional } \\ \text { Initiative }\end{array} & \begin{array}{l}\text { Post test } \\ \text { only }\end{array} & \begin{array}{l}\text { Medical } \\ \text { trainees }\end{array} & \begin{array}{l}\text { Quantitative } \\ \text { surveys and } \\ \text { informal } \\ \text { "talk back" } \\ \text { forums }\end{array} \\ & (\mathrm{n}=1401) & \begin{array}{l}\text { formats } \\ \end{array}\end{array}$

Lorenz, Steckart

and

Rosenfeld

(2004)

$\begin{array}{ll}\begin{array}{l}\text { - Audience } \\ \text { members were } \\ \text { asked to rate } \\ \text { the degree to }\end{array} & \begin{array}{l}\text { - } 61 \% \text { of respondents felt } \\ \text { that the production helped } \\ \text { them strongly or } \\ \text { moderately reflect on }\end{array} \\ \begin{array}{l}\text { helped them } \\ \text { heflect on } \\ \text { helping terminal patients } \\ \text { extend life }\end{array} \\ \begin{array}{l}\text { of-life care, } \\ \text { including } \\ \text { extension of } \\ \text { life, } \\ \text { responding to } \\ \text { physical and } \\ \text { emotional }\end{array} & \begin{array}{l}\text { - } 85 \% \text { felt that the } \\ \text { production helped them on talking with their }\end{array} \\ \end{array}$




\begin{tabular}{|c|c|c|c|c|c|c|}
\hline & & & & & $\begin{array}{l}\text { distress and } \\
\text { talking with } \\
\text { patients about } \\
\text { dying wishes } \\
\text { and prognosis. } \\
\text { - Audience } \\
\text { members were } \\
\text { asked to rate } \\
\text { the degree to } \\
\text { which the play } \\
\text { was more or } \\
\text { less useful than } \\
\text { traditional } \\
\text { teaching } \\
\text { methods, } \\
\text { including } \\
\text { lectures, } \\
\text { journal } \\
\text { readings and } \\
\text { rounds. }\end{array}$ & $\begin{array}{l}\text { - } 86 \% \text { felt that the } \\
\text { production helped them } \\
\text { strongly or moderately } \\
\text { reflect on talking with } \\
\text { patients about end-of-life } \\
\text { wishes } \\
\text { - 54\%, 62\% and 30\% of } \\
\text { respondents found that } \\
\text { learning through drama was } \\
\text { much more useful than } \\
\text { learning through lecture, } \\
\text { journal readings and } \\
\text { bedside rounds, } \\
\text { respectively. }\end{array}$ \\
\hline $\begin{array}{l}\text { Living in } \\
\text { the Bonus } \\
\text { Round } \\
\text { (AIDS } \\
\text { musical) }\end{array}$ & FT & $\begin{array}{l}\text { Post test } \\
\text { only }\end{array}$ & $\begin{array}{l}\text { Medical } \\
\text { students, } \\
\text { faculty, } \\
\text { practicing } \\
\text { physicians, } \\
\text { family } \\
\text { members } \\
\text { and } \\
\text { patients } \\
\text { (for AIDS }\end{array}$ & $\begin{array}{l}\text { Informal } \\
\text { discussion } \\
\text { and Likert } \\
\text { scale survey }\end{array}$ & $\begin{array}{l}\text { - Did the } \\
\text { performance } \\
\text { improve and/or } \\
\text { expand } \\
\text { audience } \\
\text { understanding } \\
\text { and sensitivity } \\
\text { of stated health } \\
\text { issues? } \\
\text { - Did audience } \\
\text { members gain } \\
\text { emotional and } \\
\text { psychological }\end{array}$ & $\begin{array}{l}\text { - The performance } \\
\text { improved understanding of } \\
\text { the experience of AIDS (M } \\
=5.0) \text { and ovarian cancer } \\
(\mathrm{M}=4.70)\end{array}$ \\
\hline
\end{tabular}




$\begin{array}{ll}\begin{array}{l}\text { Deep } \\ \text { Canyon }\end{array} & \begin{array}{l}\text { Ovarian } \\ \text { cancer } \\ \text { play, } \mathrm{n}= \\ 47)\end{array} \\ \begin{array}{l}\text { (Ovarian } \\ \text { cancer } \\ \text { play) }\end{array} & \end{array}$

Shapiro and Hunt

$\begin{array}{lllll}\begin{array}{l}\text { Reader's } \\ \text { Theatre }\end{array} & \text { FT } & \begin{array}{l}\text { Post- } \\ \text { test } \\ \text { only }\end{array} & \begin{array}{l}\text { Nursing } \\ \text { students }\end{array} & \begin{array}{l}\text { Reflective } \\ \text { papers }\end{array} \\ & & (\mathrm{n}=104) & \end{array}$

Pardue

\author{
musical, $\mathrm{n}$ \\ = 22; for \\ Ovarian \\ cancer \\ play, $\mathrm{n}=$ \\ 47)
}

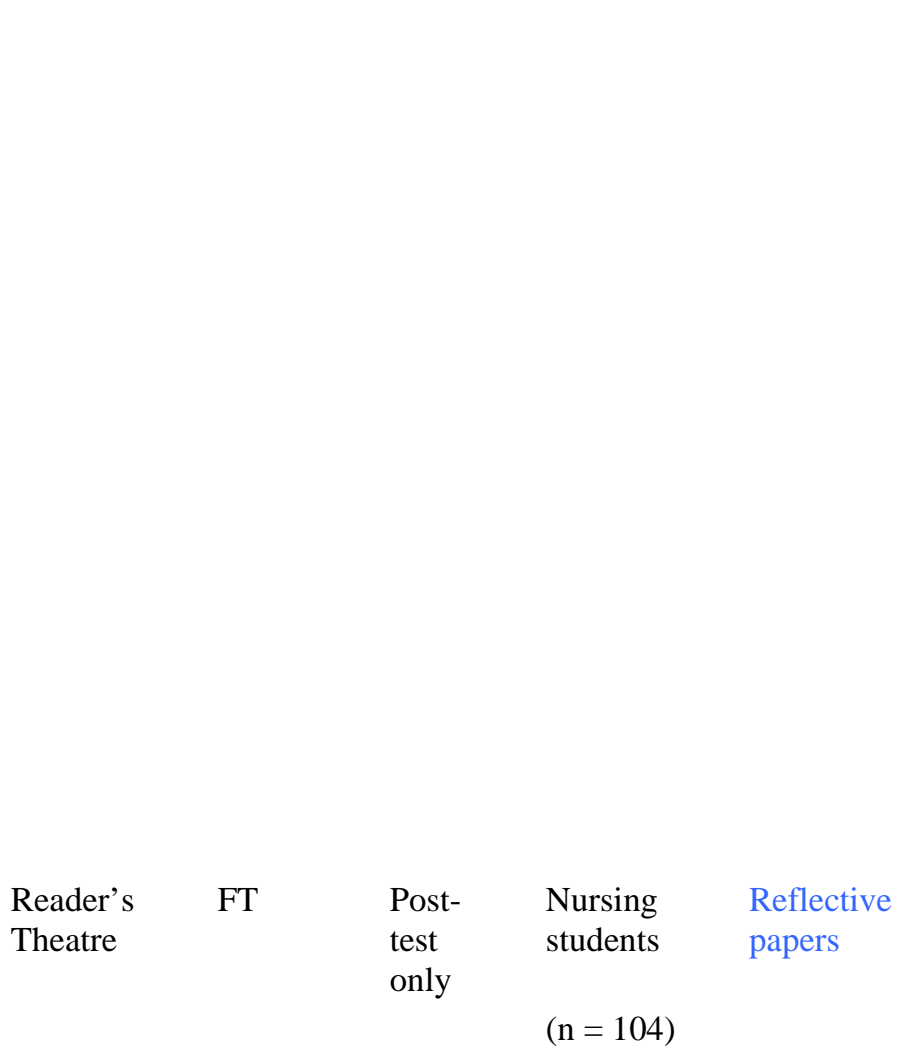

(2004)
understanding - The performance allowed of patient audience members to think experience of about AIDS related issues stated health $\quad(\mathrm{M}=4.56)$
issues?

- Did the

- The performance allowed audience members find the learning format useful for subjective learning on these issues?

for emotional and psychological insight into ovarian cancer $(\mathrm{M}=4.70)$

- The performance helped increase audience empathy for AIDS patients $(\mathrm{M}=$ 4.67) and women with ovarian cancer $(\mathrm{M}=4.81)$

- Would audience members want to attend a similar such event?

- The audience found that the format was a helpful way to learn about AIDS $(\mathrm{M}=4.78)$ and ovarian cancer $(\mathrm{M}=4.91)$

- Did audience members feel they would be able to incorporate insights gained from this performance into practice?

- The audience was interested in seeing a similar event (AIDS audience, $\mathrm{M}=4.89$, ovarian cancer audience, $\mathrm{M}=4.80$ )

- The audience felt that they would be able to incorporate insights from the play into daily practice with patients (AIDS audience, $\mathrm{M}=5.0$, ovarian cancer audience, $M=4.80$ )

- General Student papers were evaluation analyzed both for regarding enjoyment of the enjoyment and production and content of extent/area of student learning: learning that took place through the production.

\author{
- 95\% felt that it was a \\ positive edition to the \\ course
}

- 96\% felt that the postperformance discussion was beneficial to learning

- 94\% felt positively about attending other Readers 
Theatre events.

The following learning themes also arose from the papers:

- The importance of person-centred care

- The opportunity to explore empathy as a caregiving tool

- The importance of reflecting on personal experience as a means of improving practice

- The development of a positive learning community within the classroom

- Recognition of the importance of creative teaching strategies for the exploration of humanistic care

- $68 \%$ felt that their practice had changed as a

Dementia FT Care Play

McKay and Bright

((2005)

$\begin{array}{ll}\text { Practicing } & \text { Post- } \\ \text { health care } & \text { production } \\ \text { practitioner } & \text { open-ended } \\ \text { s from } & \text { questionnair } \\ \text { primary } & \text { es, } \\ \text { and } & \text { administered } \\ \text { community } & \text { both } \\ \text { care } & \text { immediately } \\ \text { settings } & \text { after the } \\ & \text { show and } \\ \text { (n= 38) } & \text { four months } \\ & \text { later }\end{array}$

- Had practice changed for audience members following the production, as a result of learning that took place through the show? result of engaging with the performance.

Changes in practice occurred in the following areas:

- Greater empathy or understanding for patient experience

- Greater empathy or understanding for family member experience 
- Improved knowledge of signs, symptoms and behaviours of persons suffering from dementia

- Greater awareness of best practices in terms of dementia care

* Genre Legend:

Non-Theatrical Performance Texts: NT

Ethnodrama, Interactive: Ed-I

Ethnodrama, Non-Interactive: Ed-NI

Theatrical Research-Based Performance Texts: TRB

Fictional Theatrical Performance: FT

** Evaluation Legend:

- Totally unstructured evaluations are coded in red

- Qualitative, or semi-structured evaluations are coded in blue

- Highly structured, quantitative evaluations are coded in green 